\title{
IMPLEMENTATION OF COOPERATIVE LEARNING MODEL NUMBERED HEADS TOGETHER STRUCTURAL APPROACH TO IMPROVE MATHEMATICAL LEARNING OUTCOMES IN CLASS VIII.3 MTs MUHAMMADIYAH O2 PEKANBARU
}

\author{
PENERAPAN MODEL PEMBELAJARAN KOOPERATIF \\ PENDEKATAN STRUKTURAL NUMBERED HEADS \\ TOGETHER UNTUK MENINGKATKAN HASIL \\ BELAJAR MATEMATIKA SISWA KELAS \\ VIII.3 MTs MUHAMMADIYAH 02 \\ PEKANBARU
}

\author{
Chindy Julia Fitrah, Syofni, Nahor Murani Hutapea \\ Pendidikan Matematika, Universitas Riau \\ Email:Chindy.juliafitrah@student.unri.ac.id
}

Submitted: (23 April 2020); Accepted: (28 Mei 2020);

Published: (31 Mei 2020)

\begin{abstract}
This study aims to improve the learning process and increase the students' mathematics learning outcomes through the implementation of the Cooperative Learning Numbered Heads Together Structural Approach. The subjects of this study were 36 students consisting of 21 male students and 15 female students. The study was conducted in the odd semester of the academic year 2019/2020. This research is Classroom Action Research with two cycles and each cycle has four stages: planning, implementation, observation, and reflection. The research instruments consist of learning instruments and data collector instruments. The learning instruments used are Syllabus, Lesson Plans, Student Activity Sheets, and the NHT question sheet. The data collector instruments are the observation sheets and math achievement tests. The observation sheet was analyzed descriptive qualitative while the test of mathematics learning outcomes was analyzed statistically. Based on descriptive qualitative analysis was obtained that implementation of the learning process on cycle II better than cycle I. The study result indicated that the implementation of the Cooperative learning model of the Numbered Heads Together Structural Approach can improve the learning process and improve mathematics learning outcomes of class VIII.3 student of MTs Muhammadiyah 02 Pekanbaru.
\end{abstract}

Keywords: Mathematical learning outcomes, Cooperative learning Numbered Heads Together structural approach, Classroom action research

\section{PENDAHULUAN}

Matematika merupakan ilmu pengetahuan universal yang berguna bagi kehidupan manusia dan juga mendasari perkembangan teknologi modern serta mempunyai peran penting dalam berbagai disiplin ilmu dan memajukan daya pikir manusia (Kemendikbud, 2014). Matematika merupakan salah satu mata pelajaran yang menduduki peranan penting dalam pendidikan. Oleh karena itu pembelajaran matematika sangat perlu diberikan kepada semua siswa dimulai dari sekolah dasar hingga sekolah menengah untuk membekali siswa dengan kemampuan dasar berpikir logis, analitis, sistematis, kritis, kreatif serta kemampuan bekerjasama.

Tujuan pembelajaran matematika di sekolah menurut Permendikbud No. 58 tahun 2014 yaitu agar siswa mampu: (1) memahami konsep matematika, (2) menggunakan pola sebagai dugaan dalam penyelesaian masalah dan mampu membuat generalisasi berdasarkan fenomena atau data yag ada, (3) menggunakan penalaran pada sifat, melakukan manipulasi matematika dalam penyerdehanaan, menganalisa komponen pemecahan masalah, (4) mengomunikasikan gagasan, penalaran 
serta mampu menyusun bukti matematika, (5) memiliki sikap menghargai kegunaan matematika dalam kehidupan, (6) memiliki sikap dan perilaku yang sesuai dengan nilainilai dalam matematika dan pembelajarannya, (7) melakukan kegiatan-kegiatan motorik yang menggunakan pengetahuan matematika dan, (8) menggunakan alat peraga sederhana maupun hasil teknologi untuk melakukan kegiatan-kegiatan matematika.

Ketercapaian tujuan pembelajaran matematika dapat dilihat dari hasil belajar matematika. Hasil belajar matematika menurut kurikulum 2013 mengharuskan siswa mencapai Kriteria Ketuntasan Minimal (KKM). KKM menurut Permendikbud No. 23 Tahun 2016 tentang Standar Penilaian Pendidikan merupakan kriteria ketuntasan belajar yang ditentukan oleh satuan pendidikan yang mengacu pada standar kompetensi kelulusan, dengan mempertimbangkan karakteristik siswa, karakteristik mata pelajaran, dan kondisi satuan pendidikan. Ketercapaian KKM dianalisis dari hasil ulangan yang diberikan guru kepada siswa setelah mengikuti proses pembelajaran. Oleh karena itu setiap siswa pada jenjang pendidikan harus mencapai KKM yang telah ditetapkan sekolah.

Pada kenyataannya masih banyak siswa yang belum dapat mencapai tujuan pembelajaran maematika tersebut. Berdasarkan data yang diberikan oleh guru mata pelajaran matematika kelas VIII.3 MTs Muhammadiyah 02 Pekanbaru, hasil belajar matematika pada materi pokok pola bilangan masih tergolong rendah, karena hanya 14 dari 36 siswa yang skor hasil belajarnya lebih atau sama dengan 77 (KKM yang ditetapkan pihak sekolah) dengan persentase siswa yang mencapai KKM adalah 38,8\%. Hal ini menunjukkan ketidaksesuaian antara hasil belajar matematika kelas VIII.3 MTs Muhammadiyah 02 Pekanbaru dengan hasil belajar matematika yang diharapkan. Peneliti melakukan pengamatan dan wawancara guru serta siswa terhadap kegiatan pembelajaran matematika. Pengamatan dan wawancara yang dilakukan peneliti bertujuan untuk mengetahui bagaimana situasi pembelajaran berlangsung dan untuk memperoleh informasi tentang permasalahan-permasalahan pada proses pembelajaran matematika.

Berdasarkan hasil wawancara dengan guru matematika diperoleh informasi bahwa siswa tidak terlibat aktif dalam proses pembelajaran, siswa cenderung pasif dan hanya menerima saja materi yang dijelaskan oleh guru, hal ini disebabkan karena kurangnya rasa ingin tahu siswa. Pada saat diberikan kesempatan bertanya oleh guru, hanya sedikit siswa yang mau bertanya kepada guru jika ada materi yang kurang dipahami siswa. Siswa lebih suka mendengar dan mencatat materi yang diberikan guru sehingga pemahaman siswa terhadap materi kurang. Pada saat diberikan latihan soal siswa mengalami kesulitan untuk mengerjakan latihan tersebut. Siswa menunggu dan menyalin jawaban dari temannya. Hal ini menunjukkan kurangnya tanggungjawab siswa terhadap proses pembelajaran.

Peneliti melakukan wawancara terhadap beberapa siswa, diperoleh informasi bahwa banyak siswa yang merasa kesulitan dalam memahami materi pelajaran matematika. Pada saat guru memberikan kesempatan bertanya, siswa tidak memiliki kepercayaan diri untuk bertanya dan siswa tidak mau maju ke depan kelas untuk mengemukakan pendapatnya ataupun mempresentasikan jawaban soal yang diberikan guru.

Peneliti juga melakukan pengamatan proses pembelajaran di dalam kelas. Pada kegiatan pendahuluan guru mempersiapkan siswa secara fisik dan psikis. Saat memulai pembelajaran, guru juga menyampaikan tujuan pembelajaran dan memotivasi siswa. Namun pada saat guru memberikan motivasi, siswa kurang memberikan respon terhadap motivasi yang diberikan guru, siswa cenderung hanya mendengarkan dan bermain. Pada kegiatan inti, pembelajaran hanya bersifat satu arah artinya guru aktif dan siswa pasif. Tidak ada interaksi aktif antara guru dan siswa. Siswa hanya mendengarkan penjelasan materi dari guru dan mencatat materi di buku catatan mereka. Saat dipersilahkan bertanya oleh guru, tidak ada siswa yang aktif bertanya. Disini terlihat kurangnya rasa ingin tahu siswa terhadap materi pembelajaran. Kemudian guru memberikan latihan soal yang dikerjakan 
secara individu, pada saat pengerjaan soal banyak siswa yang tidak bisa mengerjakan soal yang diberikan guru, karena tidak paham atas materi pembelajaran. Siswa lebih suka menunggu jawaban dari temannya dan tidak merasa bertanggung jawab untuk mengerjakan latihan soal yang diberikan oleh guru.

Pada kegiatan penutup guru tidak memberikan kesimpulan dari pembelajaran yang telah dilakukan. Hal ini bertentangan dengan Permendikbud No. 22 Tahun 2016 yang menyatakan bahwa dalam kegiatan penutup guru harus menyampaikan simpulan materi pembelajaran. Guru hanya menyampaikan cakupan materi yang akan dipelajari di pertemuan selanjutnnya pada kegiatan penutup.

Berdasarkan hasil wawancara guru dan siswa serta pengamatan yang dilakukan peneliti di kelas VIII.3 MTs Muhammadiyah 02 Pekanbaru, diperoleh permasalahan yang terjadi didalam kelas yaitu: (1) siswa tidak aktif berpartisipasi dalam proses pembelajaran; (2) Siswa kurang bertanggung jawab atas individu atau kelompok dalam proses pembelajaran, sehingga siswa menjadi tidak paham dengan materi yang diajarkan. Pada saat diberikan soal latihan siswa lebih banyak menunggu jawaban dari teman. Hal ini berdampak pada rendahnya hasil belajar matematika siswa. Untuk mengatasi masalah tersebut, perlu adanya suatu model pembelajaran yang dapat menjadikan siswa terlibat aktif dalam pembelajaran dan dapat meningkatkan tanggung jawab individu maupun kelompok di dalam proses pembelajaran. Model pembelajaran yang dapat melibatkan peran siswa secara aktif salah satunya adalah pembelajaran kooperatif, karena pada pembelajaran kooperatif ini siswa lebih aktif dalam berbicara dan berpendapat. Menurut Slavin (dalam Tran dan Lewis, 2012) pembelajaran kooperatif merupakan suatu model pembelajaran yang berpusat pada siswa, yang dapat membantu siswa memperoleh keterampilan praktis belajar, kemampuan komunikasi yang efektif dan kemampuan dalam hal pemahaman pengetahuan.

Bentuk model pembelajaran kooperatif yang dapat digunakan pendekatan struktural Numbered Heads Together (NHT). Alie (2013) berpendapat bahwa model pembelajaran kooperatif NHT memiliki kelebihan yaitu, setiap diwajibkan untuk siap menjawab pertanyaan, dapat meningkatkan prestasi belajar siswa, siswa dapat melakukan diskusi dengan sungguh-sungguh dan juga siswa yang pandai dapat mengajari siswa yang kurang pandai. Pada model pembelajaraan kooperatif pendekatan struktural NHT ini, siswa ditempatkan dalam tim belajar yang heterogen yang beranggotakan 3-5 orang, kemudian masing-masing siswa dalam kelompok diberi nomor identitas di dalam kelompoknya. Adanya penunjukan secara acak kepada setiap kelompok dalam memberikan jawaban yang di ajukan oleh guru membuat semua kelompok memastikan teman sekolompoknya memahami materi yang di berikan dalam lembar kerja. Kondisi ini tentu akan mempengaruhi interaksi antar kelompok yang lebih aktif sehingga berdampak baik pada pemahaman siswa tentang materi pelajaran, sehingga diharapkan dapat meningkatkan hasil belajar matematika. Pembelajaran kooperatif pendekatan struktural NHT adalah model pembelajaran yang menekankan pada akuntabilitas individu dalam diskusi kelompok (Huda, 2013). Lie (2010) menyatakan bahwa dalam pembelajaran kooperatif NHT setiap siswa akan diberi nomor dan dituntut untuk menyelesaikan tugas yang diberikan guru. Menurut Kurniasih dan Sani (2015) model pembelajaran kooperatif pendekatan struktural NHT memiliki beberapa kelebihan yaitu: (1) dapat meningkatkan prestasi siswa; (2) mampu memperdalam pemahaman siswa; (3) melatih tanggung jawab siswa; (4) mempermudah siswa dalam belajar; (5) membangun rasa ingin tahu siswa; (6) meningkatkan rasa percaya diri siswa; (7) mengembangkan rasa memiliki dan kerja sama; (8) setiap siswa termotivasi untuk menguasai materi; (9) menghilangkan kesenjangan antara yang pintar dan yang kurang pintar; (10) terciptanya suasana gembira dalam belajar. Yusrianti, dkk (2019) dalam penelitiannya mengatakan bahwa penerapan model pembelajaran kooperatif pendekatan struktural Numbered Heads Together dapat memperbaiki proses pembelajaran dan meningkatkan hasil belajar 
matematika siswa kelas VII SMP Negeri 17 Pekanbaru.

Berdasarkan pertimbangan di atas, peneliti melakukan penerapan model pembelajaran Kooperatif Pendekatan Struktural Numbered Head Together untuk meningkatkan hasil belajar matematika siswa kelas VIII.3 MTs Muhammadiyah 02 Pekanbaru pada materi relasi dan fungsi dengan Kompetensi Dasar 3.3 Mendeskripsikan dan menyatakan relasi dan fungsi dengan menggunakan berbagai representasi (kata-kata, tabel, grafik, diagram, dan persamaan) dan Kompetensi Dasar 4.3 Menyelesaikan masalah yang berkaitan dengan relasi dan fungsi dengan menggunakan berbagai representasi.

\section{METODE}

Penelitian ini dilaksanakan di kelas VIII.3 MTs Muhammadiyah 02 Pekanbaru, pada semester ganjil tahun pelajaran 2019/2020. Pelaksanaan tindakan ini dimulai dari 07 November 2019 sampai dengan 26 November 2019. Jenis penelitian ini adalah Penelitian Tindakan Kelas (PTK). Penelitian ini dilakukan secara kolaboratif dengan melibatkan guru matematika kelasVIII.3 MTs Muhammadiyah 02 Pekanbaru dan mahasiswa pendidikan matematika Universitas Riau yang bekerjasama dalam pelaksanaan tindakan. Penelitian ini dilakukan sebanyak dua siklus. Daur siklus pada penelitian ini mengacu pada pendapat Arikunto (2013) yang menyatakan bahwa secara garis besar penelitian tindakan kelas dilaksanakan melalui empat tahap, yaitu perencanaan, pelaksanaan, pengamatan, dan refleksi.

Subjek penelitian ini adalah siswa kelas VIII.3 MTs Muhammadiyah 02 Pekanbaru semester ganjil tahun pelajaran 2019/2020 sebanyak 36 siswa yang terdiri dari 21 siswa laki-laki dan 15 siswa perempuan dengan tingkat kemampuan akademis yang heterogen. Instrumen penelitian terdiri dari perangkat pembelajaran dan instrumen pengumpul data. Perangkat pembelajaran yang digunakan adalah Silabus, RPP, LAS dan Lembar soal NHT. Instrumen pengumpul data yang digunakan dalam penelitian ini adalah lembar pengamatan aktivitas guru dan siswa serta tes hasil belajar matematika. Data aktivitas guru dan siswa dikumpulkan dengan teknik observasi. Pengisian lembar pengamatan dilakukan dengan cara memberi tanda $(\sqrt{ })$ pada kotak jika aktivitas terlaksana dan tanda $(\times)$ jika aktivitas tidak terlaksana. Pengamat juga memberikan deskripsi tentang kesesuaian rencana pembelajaran dengan tindakan yang dilakukan untuk setiap aktivitas pembelajaran pada kolom hasil pengamatan. Sementara itu, data hasil belajar matematika siswa dikumpulkan dengan teknik tes melalui tes hasil belajar matematika.

Analisis data pada penelitian ini adalah analisis data aktivitas guru dan siswa serta analisis hasil belajar matematika siswa. Analisis data aktivitas guru dan siswa diperoleh dari hasil lembar pengamatan selama proses pembelajaran dengan membandingkan kesesuaian langkah-langkah pembelajaran di RPP dengan pelaksanaan pembelajaran. Proses pembelajaran dikatakan terjadi perbaikan apabila kualitas setiap langkah-langkah pembelajaran semakin membaik dan sudah sesuai dengan rencana. Sedangkan analisis data hasil belajar matematika dianalisis dengan statistik deskriptif. Secara rinci, data yang dianalisis pada penelitian ini yaitu sebagai berikut.

1. Analisis Data Aktivitas Guru dan Siswa

Analisis data aktivitas guru dan siswa didasarkan dari hasil lembar pengamatan selama proses pembelajaran. Analisis data aktivitas guru dan siswa ini bertujuan untuk melihat proses perbaikan pembelajaran. Analisis ini dilakukan dengan membandingkan kesesuaian langkah-langkah pembelajaran di RPP dengan langkah-langkah pembelajaran pada pelaksanaan tindakan. Proses pembelajaran dikatakan terjadi perbaikan apabila kualitas setiap langkah-langkah pembelajaran semakin membaik dan sudah sesuai dengan rencana. Pembelajaran. Kualitas pelaksanaan pembelajaran dikatakan lebih baik apabila kekurangan dan kelemahan pembelajaran yang terjadi pada siklus II lebih sedikit daripada kekurangan dan kelemahan pembelajaran pada siklus I.

2. Analisis Data Distribusi Frekuensi

Data hasil belajar matematika siswa sebelum dan sesudah tindakan dikumpulkan 
kemudian disajikan dalam bentuk distribusi frekuensi. Penyajian data menggunakan distribusi frekuensi dimaksudkan agar diperoleh gambaran yang jelas mengenai hasil belajar matematika siswa, sehingga dapat dilihat peningkatan hasil belajar matematika siswa.

Tabel 1. Distribusi Frekuensi Hasil belajar Siswa

\begin{tabular}{cc}
\hline Interval skor & Kriteria \\
\hline $0-20$ & Rendah sekali \\
$21-40$ & Rendah \\
$41-60$ & Cukup \\
$61-80$ & Tinggi \\
$81-100$ & Sangat Tinggi \\
\hline
\end{tabular}

Analisis distribusi frekuensi kompetensi pengetahuan dan analisis distribusi kompetensi keterampilan. Peningkatan hasil belajar terjadi apabila kriteria rendah dan sangat rendah mengalami penurunan frekuensi, dari sebelum tindakan ke UH I dan dari UH I ke UH II. Sedangkan untuk kriteria tinggi dan sangat tinggi terjadi peningkatan frekuensi siswa dari sebelum tindakan ke UH I dan dari UH I ke UH II.

Kriteria keberhasilan tindakan pada penelitian ini adalah sebagai berikut.

1. Terjadinya perbaikan proses pembelajaran

Proses pembelajaran mengalami perbaikan ketika proses pembelajaran pada siklus II lebih baik daripada proses pembelajaran pada siklus I, ditandai dengan kekurangan dan kelemahan pembelajaran yang terjadi pada siklus II lebih sedikit daripada kekurangan dan kelemahan pembelajaran pada siklus I.

2. Terjadinya peningkatan hasil belajar matematika siswa

Jika frekuensi siswa dengan kriteria rendah dan sangat rendah berkurang dan semakin sedikit dari sebelum dilakukan tindakan ke setelah dilakukan tindakan atau jika frekuensi siswa dengan kriteria tinggi dan sangat tinggi semakin meningkat dari sebelum dilakukan tindakan ke setelah dilakukannya tindakan, maka terjadi peningkatan hasil belajar matematika siswa. Peningkatan hasil belajar juga diperkuat dengan ketercapaian KKM yaitu jika jumlah siswa yang mencapai KKM setelah dilakukan tindakan lebih banyak dari jumlah siswa yang mencapai KKM sebelum dilakukannya tindakan. Berdasarkan paparan di atas, jika pada siklus I dan siklus II terjadi perbaikan pada proses pembelajaran dan peningkatan hasil belajar matematika siswa, maka dapat dikatakan bahwa penerapan model Pembelajaran kooperatif pendekatan struktural Numbered Head Together (NHT) dapat memperbaiki proses pembelajaran dan meningkatkan hasil belajar matematika siswa VIII.3 MTs Muhammadiyah 02 Pekanbaru

\section{HASIL DAN PEMBAHASAN}

Tindakan yang dilakukan pada penelitian ini adalah penerapan model pembelajaran kooperatif pendekatam struktural Numbered Head Togetherpada mata pelajaran matematika dengan materi pokok relasi dan fungsi di kelas VIII.3 MTs Muhammadiyah 02 Pekanbaru. Tindakan penelitian ini dilaksanakan pada semester ganjil tahun pelajaran 2018/2019, yang dimulai dari 07 November 2019 sampai dengan 26 November 2019.

Model pembelajaran kooperatif pendekatan struktural NHT memberikan dampak positif pada pelaksanaan proses pembelajaran di kelas VIII.3 MTs Muhammadiyah 02 Pekanbaru yaitu siswa menjadi lebih aktif dalam proses pembelajaran, menumbuhkan sikap kerjasama antar siswa, meningkatkan tanggung jawab individu dan kelompok untuk memahami materi dalam proses pembelajaran, meningkatkan rasa percaya diri siswa saat menjawab pertanyaan dan presentasi di depan kelas. Hal ini memberikan pengaruh terhadap hasil belajar matematika siswa.

Berdasarkan analisis lembar pengamatan aktivitas guru dan siswa selama penelitian dilakukan (6 pertemuan) dapat dikatakan bahwa pelaksanaan proses pembelajaran semakin membaik untuk setiap pertemuan. Meskipun pada siklus I masih terdapat kekurangan yang dilakukan peneliti dan siswa yaitu sebagai berikut.

Tabel 2. Kekurangan Tindakan pada Siklus I

\begin{tabular}{llll}
\hline No & Kekurangan & \multicolumn{2}{c}{$\begin{array}{c}\text { Perbaikan yang } \\
\text { akan dilakukan }\end{array}$} \\
\hline 1 & $\begin{array}{l}\text { Situasi kelas pada } \\
\text { saat awal pelajaran, }\end{array}$ & $\begin{array}{l}\text { Peneliti akan lebih } \\
\text { tegas kepada siswa }\end{array}$
\end{tabular}




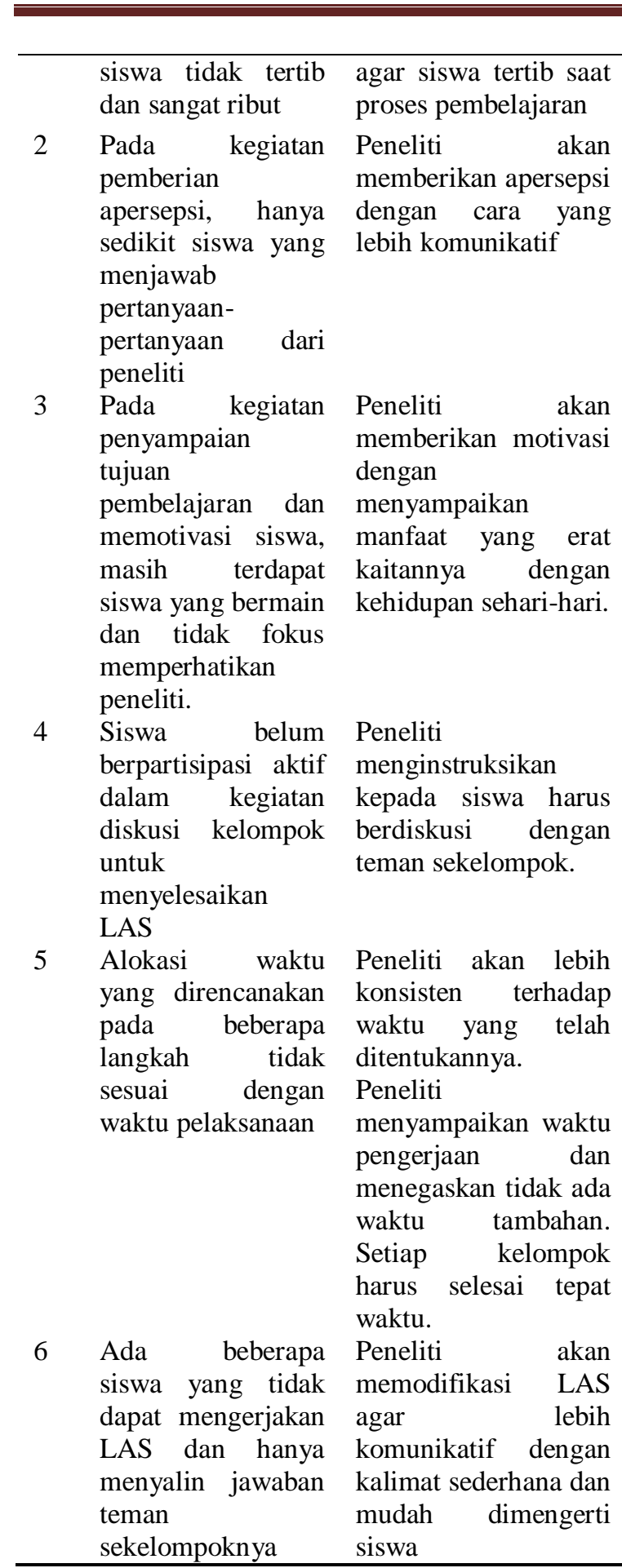

Sumber : (Olah data peneliti, 2019)

Berdasarkan Tabel 2 terlihat kekurangan-kekurangan yang terjadi pada siklus I menjadi bahan perbaikan bagi peneliti untuk melaksanakan proses pembelajaran pada siklus II. Pada siklus II peneliti telah memperbaiki kelemahan-kelemahan berdasarkan refleksi siklus I sehingga pelaksanaan proses pembelajaran mengalami

perbaikan. Siswa sudah berpartisipasi aktif di dalam proses pembelajaran hal ini ditunjukkan dengan siswa memberikan respon saat peneliti melakukan apersepsi dan motivasi. Siswa aktif bekerjasama dengan kelompok masing-masing untuk memahami dan menjawab permasalahan yang ada. Siswa sudah berani untuk mempresentasikan hasil kerja kelompok di depan kelas. Secara keseluruhan, aktivitas guru dan siswa terlaksana lebih baik pada setiap pertemuan.

Selanjutnya ditinjau dari hasil belajar matematika, peningkatan hasil belajar dilihat dari analisis distribusi frekuensi pengetahuan dan keterampilan siswa. Berikut ini distribusi frekuensi dari nilai hasil belajar matematika siswa kompetensi pengetahuan pada skor dasar, skor Ulangan Harian I dan skor Ulangan Harian II yang disajikan dalam Tabel 3.

Tabel 3. Frekuensi Skor Dasar, Skor UH I, dan Skor UH 2 Siswa

\begin{tabular}{ccccc}
\hline \multirow{2}{*}{$\begin{array}{c}\text { Interval } \\
\text { Skor }\end{array}$} & $\begin{array}{c}\text { Skor } \\
\text { Dasar }\end{array}$ & $\begin{array}{c}\text { Skor } \\
\text { UH I }\end{array}$ & $\begin{array}{c}\text { Skor } \\
\text { UH 2 }\end{array}$ & Kriteria \\
\hline $0-20$ & 0 & $\mathbf{0}$ & 0 & $\begin{array}{c}\text { Rendah } \\
\text { sekali }\end{array}$ \\
\hline $21-40$ & 9 & $\mathbf{4}$ & 1 & Rendah \\
\hline $41-60$ & 5 & $\mathbf{7}$ & 5 & Cukup \\
\hline $61-80$ & 13 & $\mathbf{1 4}$ & 15 & Tinggi \\
\hline $81-100$ & 9 & $\mathbf{1 1}$ & 15 & $\begin{array}{c}\text { Tinggi } \\
\text { sekali }\end{array}$ \\
& & & & \\
\hline
\end{tabular}

Sumber : (Olah data peneliti, 2019)

Berdasarkan data yang diperoleh dari Tabel 3 mengenai hasil belajar matematika siswa pada kompetensi pengetahuan, terlihat bahwa terjadi perubahan hasil belajar antara skor dasar, Ulangan harian I dan ulangan harian II. Frekuensi siswa yang mendapatkan kriteria rendah sekali adalah 0 . Pada kriteria rendah terjadi penurunan jumlah siswa dari skor dasar ke ulangan harian I dan ulangan harian II. Pada kriteria tinggi sekali terjadi peningkatan jumlah siswa dari skor dasar ke ulangan harian I dan dari ulangan harian I ke ulangan harian II. Data diatas menunjukkan bahwa setelah dilaksanakan tindakan terjadi 
peningkatan hasil belajar siswa pada kompetensi pengetahuan. Selanjutnya distribusi frekuensi dari hasil belajar matematika siswa pada kompetensi keterampilan pada skor dasar, ulangan harian I dan ulangan harian II disajikan pada tabel berikut ini.

Tabel 4. Distribusi frekuensi hasil belajar matematika siswa kompetensi keterampilan

\begin{tabular}{ccccc}
\hline \multirow{2}{*}{$\begin{array}{c}\text { Interval } \\
\text { Skor }\end{array}$} & \multicolumn{3}{c}{ Frekuensi Siswa } & Kriteria \\
\cline { 2 - 4 } & $\begin{array}{c}\text { Skor } \\
\text { Dasar }\end{array}$ & $\begin{array}{c}\text { Skor } \\
\text { UH I }\end{array}$ & $\begin{array}{c}\text { Skor } \\
\text { UH 2 }\end{array}$ & \\
\hline $0-20$ & 0 & 0 & 0 & $\begin{array}{c}\text { Rendah } \\
\text { sekali }\end{array}$ \\
\hline $21-40$ & 9 & 2 & 1 & Rendah \\
\hline $41-60$ & 5 & 8 & 4 & Cukup \\
\hline $61-80$ & 13 & 14 & 16 & Tinggi \\
\hline $81-100$ & 9 & 12 & 15 & $\begin{array}{c}\text { Tinggi } \\
\text { sekali }\end{array}$ \\
\hline
\end{tabular}

Sumber: (Olah data peneliti, 2019)

Berdasarkan Tabel 4 Distribusi frekuensi hasil belajar matematika siswa pada kompetensi keterampilan, terlihat perubahan hasil belajar antara skor dasar, ulangan harian I dan ulangan harian II. Pada kriteria rendah terjadi penurunan jumlah siswa dari skor dasar ke ulangan harian I dan ulangan harian II, sedangkan pada kriteria tinggi dan tinggi sekali terjadi peningkatan jumlah siswa dari skor dasar ke ulangan harian I dan dari ulangan harian I ke ulangan harian II. Penjelasan diatas menunjukka bahwa setelah dilaksanakan tindakan terjadi peningkatan hasil belajar matematika siswa pada kompetensi keterampilan yang ditandai dengan penurunan frekuensi siswa pada interval rendah serta peningkatan frekuensi siswa pada interval tinggi dan tinggi sekali.

Berdasarkan analisis data aktivitas guru dan siswa pada penerapan model pembelajaran kooperatif pendekatan struktural Numbered Heads Together, kegiatan pembelajaran sudah berjalan sesuai dengan rencana pembelajaran. Hal ini dapat dilihat dari rencana perbaikan pada hasil refleksi siklus I telah dilaksanakan dengan baik pada siklus II sehingga proses pembelajaran pada siklus II semakin membaik,
Berdasarkan pelaksanaan tindakan dari siklus I ke siklus II, siswa bertambah aktif dalam mengikuti proses pembelajaran. Penerapan model pembelajaran kooperatif pendekatan struktural NHT menjadikan siswa bertanggung jawab secara individu dan juga kelompok dalam proses pembelajaran, serta meningkatkan rasa percaya diri siswa untuk mempresentasikan hasil kerja kelompoknya di depan kelas. Berdasarkan analisis data tabel distribusi frekuensi Tabel 3 tentang hasil belajar matematika siswa kompetensi pengetahuan dan tabel 4 pada kompetensi keterampilan dapat dilihat peningkatan hasil belajar matematika siswa dari sebelum tindakan ke setelah tindakan yaitu frekuensi siswa pada kriteria rendah dan sangat rendah terjadi penurunan dari skor dasar ke skor UH I dan ke skor UH II serta frekuensi siswa pada kriteria tinggi dan sangat tinggi terjadi peningkatan dari skor dasar ke skor UH I dan ke skor UH II.

Berdasarkan uraian tentang analisis data aktivitas guru dan siswa, serta analisis data hasil belajar matematika siswa dapat dikatakan bahwa terjadi perbaikan proses pembelajaran dan meningkatnya hasil belajar matematika siswa sehingga berdasarkan hasil analisis penelitian tersebut, dapat dikatakan jika model pembelajaran kooperatif pendekatan struktural Numbered Heads Together diterapkan, maka dapat memperbaiki proses pembelajaran dan meningkatkan hasil belajar matematika siswa kelas VIII.3 MTs Muhammadiyah 02 Pekanbaru pada semester ganjil tahun pelajaran 2019/2020 materi pokok relasi dan fungsi.

\section{SIMPULAN}

Berdasarkan hasil penelitian dan pembahasan, dapat disimpulkan bahwa penerapan Model Pembelajaran Kooperatif Pendekatan Struktural Numbered Heads Together dapat memperbaiki proses pembelajaran dan meningkatkan hasil belajar matematika siswa kelas VIII.3 MTs Muhammadiyah 02 Pekanbaru pada semester ganjil tahun pelajaran 2019/2020 pada materi pokok relasi dan fungsi. 
Volume 2, Nomor 2, Mei 2020

DOI: https://doi.org/10.33578/prinsip.v2i2.45

jprinsip.ejournal.unri.ac.id

\section{REKOMENDASI}

Melalui penelitian yang telah dilakukan, peneliti mengemukakan rekomendasi yang berhubungan dengan penerapan model pembelajaran kooperatif pendekatan struktural Numbered Heads Together dalam pembelajaran matematika, yaitu:

1. Penerapan model pembelajaran kooperatif pendekatan struktural Numbered Heads Together (NHT) dapat dijadikan salah satu alternatif model pembelajaran yang bisa diterapkan untuk memperbaiki proses pembelajaran dan meningkatkan hasil belajar matematika siswa.

2. Pada pelaksanaan model pembelajaran kooperatif pendekatan struktural Numbered Heads Together diharapkan guru atau peneliti selanjutnya dapat mengatur waktu dengan baik karena dalam pelaksanaan pembelajaran ini sangat membutuhkan waktu pengerjaan lebih lama.

\section{DAFTAR PUSTAKA}

Alie, N.H. (2013). Penggunaan model pembelajaran kooperatif tipe NHT untuk meningkatkan hasil belajar siswa kelas X2 SMA Neg. 3 Gorontalo pada materi jarak pada bangun ruang. Jurnal Entropi, 7(1), $583-592$

Arikunto, S. (2013). Prosedur penelitian suatu pendekatan praktik. Rineka Cipta

Kemendikbud. (2014). Salinan Lampiran Permendikbud No. 58 Tahun 2014 Tentang Kurikulum 2013 Sekolah Menengah Pertama/Madrasah Tsanawiyah. Kemendikbud
Kemendikbud. (2016). Salinan Lampiran Permendikbud No. 22 Tentang Standar Proses Pendidikan Dasar dan Menengah. Kemendikbud

Kemendikbud. (2016). Salinan Lampiran Permendikbud No. 23 Tentang Standar Penilaian Pendidikan. Kemendikbud

Kurniasih, I. \& Sani, B. (2015). Ragam pengembangan model pembelajaran. Kata Pena

Lie, A. (2010). Cooperative learning. Grasindo

Huda, M. (2013). Model Pengajaran dan Pembelajaran. Pustaka Belajar

Tran, V., \& Lewis, R. (2012). The effects of jigsaw learning on students' attitudes in a Vietnamese Higher Education classroom. International Journal of Higher Education, $1(2), \quad 9 \quad-\quad 20$. https://doi.org/10.5430/ijhe.v1n2p9

Yusrianti, P., Jalinus, \& Suhermi. (2019). Penerapan model pembelajaran kooperatif pendekatan struktural Numbered Head Together untuk meningkatkan hasil belajar matematika siswa kelas VII SMP N 17 Pekanbaru. JOM FKIP Universitas Riau, 3(2), 1-13 